\title{
ПРОФЕССОР М. Б. БЛАУБЕРГ
}

Жизнь и деятельность фармацевта и гигиениста профессора Магнуса Богдановича Блауберга (Carl Magnus Blauberg) до сих пор не нашла должного освящения.

Магнус Блауберг родился 13(25) марта 1866 года в г. Вольмаре Лифляндской губернии Российской империи (ныне Валмиера, Латвия) в лютеранской семье потомственного почетного гражданина.

В 1881 г., не окончив Рижской классической гимназии, он из пятого класса поступил аптекарским учеником в апrтеку И. Дрекслера в Риге. Через три года М. Блауберг сдал экзамен на звание аптекарского помощника в Императорском Дергтском университете (с 1893 г. Юрьевский, ныне Тартуский в Эстонии). ${ }^{1}$ После этого он, в том же 1884 году, начал работать в аптеке Папе в г. Ефремове Тульской губернии. После двухлетнего стажа, необходимого для поступления на фармацевтическое отделение университета, аптекарский помощник М. Блауберг стал заниматься в Императорском Московском университете. Одновременно - в 1886-1889 гт. - он работал в Староникольской аптеке К. И. Феррейна в Москве.

В 1889 г. определением совета Московского университета М. Блауберг утвержден в звании провизора ${ }^{2}$. Затем, с ноября 1890 г. он занимался в Гигиеническом институте Московского университета у проф. Ф. Ф. Эрисмана (1842-1915), а с февраля 1891 г. по март 1893 г. исполнял обязанности химика-аналитика на открытой при гигиеническом институте городской санитарной станции. Эта станция была учреждена при гигиеническом институте университета постановлением Московской городской думы с тем, чтобы руководство станцией было возложено на проф. Ф. Ф. Эрисмана как на лицо, наиболее авторитетное и сведущее в этой области. ${ }^{3}$

1 Исторический архив Эстонии (ИАЭ), ф. 402, on. 2, д. 2088 (Личное дело аптекарского помощника М. Блауберга).

2 Центральный государственный исторический архив г. Москвы (ЦГИАМ), ф. 41S, on. 58, д. 192 (О допущении аптекарского помощника М. Блауберга к испытанию на степень провизора).

3 И. И. Резанов. К 100-летию Московской городской санитарной станции// Гигиена и Санитария. - 1991. - №5.-С.76-78. 
На станции М. Блауберг принимал не только деятельное участие в исследовании пищевых продуктов, которые производились по поручению Московской городской управы, но провел ряд самостоятельных работ: "Исследование продажного московского ржаного хлеба", "Виноградное вино", "Исследование загрязненных почв", "О продажсном уксусе и уксусной эссенции». Они были опубликованы в отчетах городской санитарной станции за 1891-1893 годы. В бытность свою на станции, М. Блауберг много помогал, по свидетельству проф. Ф. Ф. Эрисмана, ему в руководстве занятиями работающих в Гигиеническом институте врачей и при этом обнаружил «несомненные преподавательские способности».

Особо надо выделить выполненную М. Блаубергом диссертацию на степень магистра фармации под заголовком "Русское виноградное вино и херес" ${ }^{4}$. Исходя из мысли, что правильная оценка в химико-санитарном отношении того или другого вина чрезвычайно затруднительна отсутствием данных о составе натуральных вин и об отношениях, в которьх в этих винах находятся отдельные составные части, М. Блауберг поставил себе задачи: во-первыг, подвергнуть возможно подробному анализу известное количество натуральньг вин, и, вовторых, выяснить, каким образом можно пользоваться аналитическими данными для суждения о натуральности и о доброкачественности вина. Объектом исследования послужила 31 проба натурального вина с Южного берега Крыма, 21 проба фальсифицированных бельх и красных вин и 21 проба продажного хереса. Проведя подробные анализы, М. Блауберг в значительной степени обогатил скудные сведения о химическом составе русских вин. Кроме того, он дал подробное изложение методов исследования виноградных вин и критический разбор оценки результатов их. Проф. Эрисман писал, что этим трудом он «оказал больиую услугу русскаму виноделию, и имеет полное право сказать, что он старался посильно содейстьовать устранению тех затруднений, которые 6 настоящее время өстречает борьба с фальсификаиией вина».

Успешная зашита диссертации состоялась в 1894 г. на медицинском факультете Московского университета. ${ }^{5}$ За эту работу, в том же 1894 г., на Международной выставке виноделия, плодоводства и садоводства в Санкт-Петербурге М. Блаубергу был присужден «почетный диплам, заменяючий залотую медаль».

4 М. Б. Блауберг. Русское виноградное вино и херес: Состав, методы исследования, основы химико-санитарной оценки и фальсификации их.Москва, 1894.- ХХ. - 351 с.

5 ЦГИАМ, ф. 418, оп. 58, д 306 (О допущении провизора А. Блауберга к испытанию на степень магистра фармации); там же, ф. 418, оп. 63, д. 246 (О защите провизором Блаубергом диссертащии на степень магистра фармации); там же, ф. 418 , оп. 401, д. 73 (О диссертации на степень магистра фармации М. Б. Блауберга). 
Итак, исследования, выполненные под руководством проф. Ф. Ф. Эрисмана положили начало одному из основных направлений в научной деятельности М. Б. Блауберга - изучению проблем гигиены и физиологии питания.

В Москве М. Блауберг состоял действительным членом Московского гигиенического общества, Московского химического общества и Общества любителей естествознания, антропологии и этнографии. Здесь, в Москве, он женился на Луизе-Марии-Шарлотте Шмейль, лютеранского вероисповедания. В 1891 г. родился первенец - Александр, а в 1899 г.-Магнус-Адольф-Евгений. ${ }^{6}$ Параллельно с работой в Московской городской санитарной станции, М. Блауберг продолжает пополнять своё образование. Ещё в 1889 г. он занимался в Московском университете химией у проф. В. В. Марковникова (1837-1904) и приват-доцента М. И. Коновалова (1858-1906), а летом этого же года-анатомией растений у проф. И. Н. Горожанкина (1844-1904). В 1889/90 академическом году слушал в качестве стороннего слушателя в университете лекции по анатомии, гистологии и физиологии, а в 1894/95 учебном году - обязательные лекции для студентов медиков 3 курса. Летом 1890 г. он усовершенствовался по химии в Висбадене у проф. Р. Фрезениуса (R. Fresenius; 1818-1897), где, после окончания курсов по качественному, количественному и органическому анализу, был оставлен в качестве ассистента, каковую должность впоследствии занимал вторично (летом 1894 г).

В 1895 г. для окончания медицинского образования М. Блауберг снова едет заграницу, где слушает лекции и посещает клиники в Цюрихском, Вюрцбургском и Берлинском университетах. В каникулярное время он работал у гигиенистов: в 1895 г. у проф.О. Высс (О. Wуss; 1840-1918) в Цюрихе, в 1895-1896 гт. у проф. К. Лемана (К.B.Lehmann; 1858-1940) в Вюрцбурге и в 1896-1897 гт. у проф. М Рубнера (M. Rubner; 1854-1932) в Берлине. В Гигиеническом институте проф. К. Лемана он приступил к разработке вопроса об искусственном вскармливании детей ${ }^{7}$. В Берлине им подготовлена и издана

6 Он в 1917 г. окончил 1 Петербургскую гимназию и в этом же году поступил на медицинский факультет Новороссийского университета. Дальнейшая

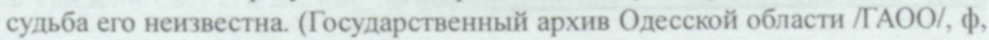
45, оп. 18, д. 943: Дело студента М.-А.-Е. Блауберга). В последующем брак распался и уже в Одессе проф. М. Блауберг живет один.

7 M. Blauberg. Beiträge zur Kenntnis der chemischen Zusammensetzung einiger Kindernahrungsmittel, nebst kurzen Angaben über die chemischen Untersuchugsmethoden derselben und den gegenwärtigen Stand der Frage der künstlichen Kinder-Ernähnung/l Archiv für Hygiene.- 1896.- Bd. 27, Heft 2.- S. 119-175; M. Blauberg. Ueber die chemische Zusammensetzung einiger "Năhrsalze", nebst kurzen Bemerkungen über die Bedeutung der Mineralstoffe für den Organismus// Archiv für Hygiene. - 1897.- Bd. 30, Heft 2.- S. 95-124; M. Blauberg. Weitere Untersuchungen über Kindernahrungsmittel, nebst kurzen Bemerkungen über die mikroskopische und bacteriologische Prüfung derselben// Archiv für Hygiene.- 1897.- Bd. 30, Heft 2.- S. 125-155. 
монография "Experimentelle und klinische Studien über Länglings fäces, mit besonderer Berücksichtigung der Mineralstoffe und Untersuchungsmethoden"8. Позднее, в летнее каникулярное время 1898, 1899 и 1900 годов, он снова приезжает к проф. М. Рубнеру, чтобы продолжить работать над проблемой рационального вскармливания детей. В связи с этим он изучает минеральный обмен у естественно и искусственно вскармливаемых грудных детей, полный обмен веществ (газовый, органический, минеральный, тепловой) у лиц различного возраста при исключительно молочной диете и мясном режиме.

В 1897 г. в Берлинском университете М. Блауберг получил степень доктора медицины и хирургии после защиты диссертации под заголовком «Ueber die Mineralbestandtheile der Sauglingsfäces bei natürlicher und künstlicher Ernährung während der ersten Lebenswochen ${ }^{9}$.

Вернувшись в Российскую империю, М. Б. Блауберг поступил на службу ассистентом Фармакологического института Юрьевского университета к проф. С. И. Чирвинскому (1852-1922); в этой должности он состоит в 1898-1901 годах. В 1901 г. постановлением совета университета он был допущен к чтению лекций по токсикологии в качестве приват-доцента. Однако, в связи с отъездом из Юрьева он не приступил к чтению своего приват-доцентского курса. ${ }^{10}$ В Юрьеве он подготовил монографию о виноградном соке, которая явилась логическим продолжением его работ начатых у проф. Ф. Ф. Эрисмана ${ }^{11}$. Здесь, в 1900 г., М. Б. Блауберг, как доктор медицины иностранного университета, выдержав экзамены, получил право свободной врачебной практики в Российской империи. Тогда же он участвует в работе III Всероссийского фармацевтического съезда, произнося речь " $O$ идеале современной фармации и о путях, ведуцих к нему" на торжественном закрытии этого научного форума. ${ }^{12}$

В 1902 г. начинается одесский период жизни М. Б. Блауберга. В этом году 19 января (1 февраля) - высочайшим приказом он был назначен профессором по кафедре фармации с фармакогнозией Императорского Новороссийского

8 Berlin, 1897.-120 S.

9 München, 1897.-325 S.

10 ИАЭ, ф. 384 , оп. 1 , д. 3295 (Личное дело ассистента М. Блауберга); там же, ф. 402, оп. 3, д.121 и 122 (Личные дела преподавателя М. Блауберга).

11 М. Б. Блауберг. О химическом составе и санитарном значении пастеризованного (небродившего) виноградного сока.- Москва, 1898.-114 с.

12 Речь, произнесенная М. Б. Блаубергом в актовом зале Императорского Московского университета в день торжественного закрытия Высочайше разрешенного III Всероссийского фармацевтического съезда (5-го января 1900 года). - Москва, 1900.- 23 с. 
университета. Он стал организатором и первым заведующим этой кафедры. Проф. М. Блауберг возглавлял кафедру, которая стала всецело его детищем, до последних дней своей жизни. В сентябре 1903 г. при кафедре фармации с фармакогнозией открывается образцовый фармацевтический институт, в котором получило образование несколько поколений провизоров. Среди учеников проф. М. Блауберга - Г. И. Мадлисон и И. Г. Кутателадзе; последний был учеником и проф. П. Я. Борисова (1864-1916).

Гарри Эрнст Иоганович Маллисон родился в 1878 г. в семье купща, лютеранского вероисповедания. В 1902 г. получил звание провизора при Юрьевском университете и в 1905-1910 годах состоит сверхштатным лаборантом кафедры фармации с фармакогнозией Новороссийского университета. Здесь он подготовил диссертацию на степень магистра фармации под заголовком «К вотросу $о$ галеновых препаратах (Galenica)" и в 1908 г. успешно защитил ее на совете медицинского факультета университета. ${ }^{13}$

Иовель Григорьевич Кутателадзе (1887-1963) - основоположник научной фармации в Грузии, создатель и бессменный руководитель фармакохимического научно-исследовательского института (ныне имени И. Г. Кутателадзе), в 1905 г. был решением медицинского факультета Новороссийского университета удостоен звания аптекарского помошника, в 1908-1910 годах обучался на фармацевтическом отделении медицинского факультета этого же университета, по окончании которого получил диплом на звание провизора. В ноябре 1911 г. его приглашает проф. М.Блауберг занять должность сверхштатного лаборанта в фармацевтическом институте, которую И. Г. Кутателалзе занимал до конца 1912 года. После смерти проф. М. Блауберга (в 1921 г.), он стал его преемником, возглавляя кафедру до конца 1921 г., когда был переведен в Тифлисский университет (ныне Тбилисский, Грузия) ${ }^{14}$, а в 1922 г. кафедра фармации с фармакогнозией ввиду изменения программы обучения была упразднена.

В Одессе М. Б. Блауберг опубликовал фармакологический справочник ${ }^{15}$, здесь увидели свет его лекции по фармакогнозии ${ }^{16}$. Следует добавить, что в

13 ГА ОО, ф. 45, оп. 4, д. 1464 (О службе Г. И. Маллисона); там же, ф. 45, оп. 18, д. 174 (Переписка о движении по службе Г. И. Мадлисона).

14 ГА ОО, ф. 45, оп. 5, д 7279 (Дело фармацевта И. Г. Кутателалзе); там же, ф.45, оп. 18, д. 411 (Переписка о движении по службе И. Г. Кутателадзе); там же, ф. 45 , оп. 18, д.644, лл. 162-163 (Curriculum vitae И. Г. Кутателадзе).

15 М. Б. Блаубере. Краткий фармакологический обзор новых медикаментов. Москва, 1902.-112 с.

16 М. Б. Блауберг. Конспект лекций по фармакогнозии, читанных в Императорском Новороссийском университете в 1902/03 академическом году. Составили студенты Л. Листенгартен и И. Корнман.- Одесса, 1903.-120 с. 
научном наследии профессора имеются работы, которые касаются истории медицины и фармации в России. Это статьи о фармацевтах А. К. Феррейне 17 и проф. Ю. К. Траппе (1814-1908) 18 , о санитарном враче П. П. Белоусове $(1856-1896)^{19}$ и об учителе его проф. М. Рубнере 20 . Он также автор ряда статей в Энциклопедическом словаре Брокгауза и Ефрона 21.

15 января 1921 г. проф. М. Блауберг добровольно ушел из жизни, отравившись цианистым калием. Был похоронен на одесском кладбище; могилу нам разыскать не удалось.

В некрологе, посвященном памяти профессора Магнуса Богдановича Блауберга, профессор анатомии Новороссийского университета Н. К. Лысенков (1803-1941) отметил, что М. Блауберг был «ученый, страстно обожсабиий науку, которую он любил называть международной религией. < ..> Обладая дарам красноречия и глубокой сердечности, покойный Магнус Богданович пользовался больиой популярностью, как среди слуиателей, так и среди своих коллег. По своему духовнаму складу он представлял собой в высией степени симпатичный, хотя и редкий в настояшее время, тип университетского

17 Речь, сказанная М.Б. Блаубергом у могилы Андрея Карловича Феррейна.Москва, 1895.-4 с.

18 М. Б. Блауберг. Биографический очерк Нестора русской фармации, почетного члена Императорской военно-медицинской академии, академика и заслуженного профессора Юлия Карловича Траппа.- Москва., 1901.- 14 с.; он же. Трапп Ю. К.// Энциклопедический словарь Брокгауза и Ефрона.СПб., 1901.- Кн. 66.- С. 727-728.

19 М. Б. Блауберг. Петр Петрович Белоусов (некролог)// Журнал русского общества охранения народного здравия.- 1896.-№9.- С. 810-812.

20 М. Б. Блауберг. Рубнер М.// Энциклопедический словарь Брокгауза и Ефрона.- СПб., 1899.- Кн. 53.- С. 206. [Подпись: М.Б.]

21 М. Б. Блауберг. Пиво в санитарном отношении// Энциклопедический словарь Броктауза и Ефрона.- СПб., 1898.- Кн. 46.- С. 568-571; Он же. Ром в санитарном отношении// Там же.- СПб., 1899.- Кн. 53.- С. 87-89; Он же. Ртуть. Медико-санитарный очерк //Там же.- СПб.,1900.- Кн. 53.- С. 186-194; Он же. Светильный газ. Медико-саннтарный очерк// Там же.- СПб., 1900.- Кн. 57.- С. 208-212; Он же. Свинец. Медико-санитарный очерк// Там же.- СПб., 1900.- Кн. 57.- С. 133-139; Он же. Сельтерская вода// Там же.- СПб., 1900.-Кн. 57.- С. 420421; Он же. Сидр// Там же.- СПб., 1900.-Кн. 58.-С. 848-850; Он же. Спиртные напитки// Там же.- СПб., 1900.- Кн. 61.- С. 228-234; Он же. Спорынья// Там же.- СПб., 1900.- Кн. 61.- С. 301-304; Он же. Трупные алкалоиды// Там же.СПб., 1902.-Кн. 67.- С. 2-3; Он же. Трупный яд// Там же.- СПб., 1902.- Кн. 34.С. 2-3; Он же. Трупные пятна// Там же.- СПб., 1902.- III. 34.- С. 4; см. также 18 и 20. 
профессора, горячо любячего не только науку, но и ее храм - дорогую аlта matern. 22

Газета "Общее дело», которая издавалась в Париже политическими эмигрантами, беженцами из Советской России, так же откликнулась на кончину профессора. Некролог в «Общем деле» дает дополнительные штрихи к портрету М. Б. Блауберга как человеку науки, показывает атмосферу в стране в первые годы после захвата власти большевиками, ту атмосферу, в которой жил и из которой должен был уйти профессор. Он оставил письмо, сообщала газета, в котором писал, что «всю жизнь посвятил науке, вне которой для него нет смысла суцествования. Жить так, как приходится теперь, в постоянной борьбе за хлеб и житейские мелочи, он не может и кончает с собой. Остаюцимся он завециает любить университет и науку, и верить в победу истины.»

И далее: «Самоубийство произвело в городе огромное впечатление. И. действительно, это был потрясаючий протест против непереносимых условий духовного гнета и обницания, в которых влачат теперь в России свою жсизнь люди мысли и культуры.

Посмертное письмо, написанное в лирическом тоне, с латинскими стихами в конце, без единого политического намека, также подчеркивало глубину внутренней драмы, отказа людей от жизни, у которой невольно, силой неодолимых обстоятельсть, ускользает оправдываючий её высокий смысл.

Похороны были необычны. Ни одного красного знамени, белые ленты бенков, свяченник, пение "Вечная память", и в густой толпе студентов печальные, изможденные лица той небольшой кучки людей, которые составляют интеллигенцию города. <..>

На гражданской панихиде о покойнам было сказано несколько теплых и волнуючих речей и только какой-то коммунистический оратор пытался доказать, что виною гибели проф. Блауберга был царский режим, т. к. Кассо ${ }^{23}$ не утвердил Блауберга на кафедру гигиены.» 24

22 Н. К. Лысенков. Проф. М Б. Блауберг (Некролог)// Современная медицина1921.- №1.- C. 121.

23 Л. А Кассо (1865-1914) - министр народного просвешения в 1911 - 1914 гr.

24 Смерть проф. Блауберга// Общее дело.- 1921 - 25 апреля, №284.- С.4. 


\section{Professor M.B. Blauberg (Summary)}

By Konstantin K. Vasilyev

This research into the life and activities of the Riga born pharmaceutist and hygienist Magnus Blauberg (1866-1921). Having finished the classical high school in Riga, he studied at the Tartu and Moscow Universities. At the same time he went through qualifications in Zürich, Berlin and Würzburg. In 1897 he defended his doctor's thesis at the University of Berlin. Having returned to Russia, he worked at the Tartu University, later till the end of his life he worked at the Novorosijsk University in Odesa.

Константин Константинович Васильев, докт. мед. наук, профессор Аб.я. 36,

Сумы-35

Украина 244035 